\title{
SUSTENTABILIDADE E DIVERSIFICAÇÃO CONCEITUAL
}

Moises da Silva Martins ( Doutorando)

Universidade do Oeste Paulista - UNOESTE

\section{RESUMO}

No sentido generalizado, com um olhar mais amplo, a sustentabilidade tem sido tratada como a capacidade de antever problemas que poderão acontecer no futuro, fazendo previsões das necessidades que a sociedade poderá ter futuramente, mesmo que estas ainda estejam indefinidas. Neste artigo através de pesquisa bibliográfica, tento esclarecer a definição de sustentabilidade considerando a diversificação conceitual de forma natural.

Palavras-chave: economia, endogenia, resiliência e meio ambiente.

\section{INTRODUÇÃO \\ MÉTODO E OBJETIVO}

Há muitos anos, o termo desenvolvimento foi eleito como pauta das discussões sobre sustentabilidade e trouxe, consigo, por meio da ecologia, pilares que hoje são debatidos e que buscam soluções para a sustentabilidade ambiental, social e econômica. Neste artigo, pretendese, mediante um estudo bibliográfico, tentar definir sustentabilidade em diversos setores.

\section{Considerações sobre sustentabilidade}

Acredita-se que ser sustentável implica em novas formas de se posicionar perante os objetivos da economia capitalista, que tem sido responsável pelo desenvolvimento econômico e pela acentuação das desigualdades sociais. Para o capitalismo, parece lógico e ideal um crescimento sem limites e desenfreado, mas para isso, não existe, mais, espaço, porque, além de não permitir a renovação dos recursos naturais, o exagero na busca do enriquecimento tem favorecido uma minoria de países em detrimento de outros.

Para melhor entender-se a sustentabilidade e como esta é influenciada pelo setor capitalista, é preciso darem-se relevâncias a conceitos, como endogenia, resistência e resiliência. Por exemplo, a endogenia, na qual países implementam as suas estratégias, olhando somente para sua realidade, seus recursos, seu território, buscando unicamente o seu interesse. A resiliência na qual os países têm a capacidade de absorção das estratégias e das concorrências; e a resistência, que é a capacidade de resistir-se aos ataques estratégicos, sejam quais forem. 
Outro aspecto relevante,para (Arnt,2011), é que a estratégia não exclui as possibilidades, mas as integram; ou seja, quanto mais desenvolvido for um país internamente, melhores serão as condições de sua inserção no mercado externo.

Sachs (2007) entende que são necessários os ajustes dos desequilíbrios gerados pelo próprio crescimento econômico; a concentração de riquezas com distribuição de renda desigual interna e externamente. Afirma, ainda, que é tão importante ajustar-se a economia interna quanto participar ativamente dos fóruns internacionais, para pressionar um novo consenso mais equilibrado e solidário entre as nações.

Parece lógico que a estratégia que equilibra também desequilibra; se considerar a sustentabilidade, que ultimamente se tornou um princípio que afirma que o uso dos recursos naturais, para as necessidades de hoje, não pode comprometer as necessidades futuras.

Recentemente, a procura de um sistema sustentável trouxe preocupações com os problemas ambientais. Preocupações que foram classificadas em etapas, sendo que a primeira se baseia na percepção de problemas ambientais localizados e atribuídos à ignorância, à negligencia, à indiferença das pessoas e dos agentes produtores e consumidores de bens e serviços. Numa segunda etapa, a degradação ambiental que é perceptiva como um problema generalizado, porém confinado nos limites territoriais de cada estado. Na terceira etapa, a degradação ambiental é percebida como um problema planetário que atinge a todos e que decorre do tipo de desenvolvimento praticado pelos países.

Em 1991, algumas entidades ambientais reconheceram a importância do entendimento das relações de interdependências entre economia e desenvolvimento e utilizaram as seguintes expressões: desenvolvimento sustentável, economia sustentável e uso sustentável. Afirmaram que o desenvolvimento sustentável serve, para indicar melhoria da qualidade de vida, respeitando os limites da capacidade dos ecossistemas; economia sustentável serve para indicar a economia que resulta de um desenvolvimento sustentável e que, portanto, conserva a sua base de recursos naturais, enquanto o uso sustentável serve, para indicar a utilização de recursos renováveis de acordo com a sua capacidade de reprodução. Para essas entidades, o desenvolvimento deve apoiar-se nas pessoas e na conservação da biodiversidade e dos processos naturais que sustentam a vida na terra, tais como os que reciclam a água, purificam o ar e regeneram o solo.

No sentido multivariado da sustentabilidade, no que tange aos recursos naturais, é imprescindível entender-se que destes depende a agricultura, pois a mesma é que vai fornecer alimentos e fibras para a raça humana e que irá contribuir para as necessidades de bicombustíveis, 
melhorar a qualidade ambiental, viabilizar a economia e consequentemente, a qualidade de vida dos agricultores. Mas os desafios da sustentabilidade agrícola estão no crescimento populacional, nos padrões e no consumo de alimentos que sofrem mudanças constantes e crescentes. Também a escassez de recursos naturais, a degradação ambiental, alterações climáticas e a reestruturação econômica global.

Contudo, baseadas no equilíbrio e no desequilíbrio, apareceram mudanças e inovações nas práticas agrícolas e em seus sistemas; e os avanços tecnológicos têm gerado resultados promissores, para melhorar a sustentabilidade agrícola, pois têm melhorado a consciência e a preocupação com os mesmo por parte dos consumidores sobre as fontes de alimentação e como elas são produzidas.

\section{CONCLUSÃO}

Então, parece claro que a sustentabilidade é um conceito complexo e dinâmico, que inclui diversos fatores ambientais que estão relacionados com os recursos econômicos e com todas as questões ambientais. Portanto, a sustentabilidade de qualquer prática é um ato social e político, que precisa basear-se no entendimento da pesquisa científica e que a mesma venha resolver os problemas ambientais, sociais e políticos no contexto mundial. É conclusivo,que os diversos setores apontados neste artigo devem estar sempre juntos e estudados sob a forma de teia.

\section{REFERÊNCIAS}

ARGENTI, P. A.. Comunicação empresarial: a construção da identidade, imagem e reputação. Tradução:Adriana Rieche. Rio de Janeiro: Elsevier, 2006.

Arnt,Ricardo.(2011) O que os economistas pensam sobre sustentabilidade.São Paulo Ed. Repor; 2011.

ASHLEY, P. Ética e Responsabilidade Social nos Negócios. São Paulo: Saraiva, 2005.

GODOY, A. S.. Pesquisa qualitativa: tipos fundamentais. Revista de Administração de Empresas. FGV-SP. São Paulo, vol.35, n.3, p. 20-29, maio/jun, 1995.

HART, S. O capitalismo na encruzilhada: As inúmeras oportunidades de negócios na solução dos problemas mais difíceis do mundo. Porto Alegre: Bookman, 2005.

SACHS, I. Ecodesenvolvimento: crescer sem destruir. São Paulo: Vértice, 1986.

SACHS, I. Rumo à Ecossocioeconomia - teoria e prática do desenvolvimento. São Paulo: Cortez Editora, 2007. 
SACHS, Ignacy, Estratégias de transição para o século XXI: desenvolvimento e meio ambiente. São Paulo:

Studio Nobel: Fundação do desenvolvimento administrativo (FUNDAP), 1993.

SACHS, Ignacy. Caminhos para o desenvolvimento sustentável. Coleção Idéias Sustentáveis. Ed. Garamond,2006.

TACHIZAWA, T. Gestão ambiental e responsabilidade social corporativa: estratégias de negócios focadas na realidade brasileira. 4a ed. São Paulo: Atlas, 2006. 